\title{
Effects of Short and Long-term Dietary Protein Restriction on the Rumen Fermentation Activity in Growing Lambs
}

\author{
J. S̆IMƯNEK ${ }^{1}$, A. WÓJCIK-GŁADYSZ ${ }^{2}$, M. WAŃKOWSKA ${ }^{2}$, P. KREJČÍ ${ }^{1}$, J. POLKOWSKA ${ }^{2}$ \\ ${ }^{1}$ Institute of Animal Physiology and Genetics, Czech Academy of Sciences, Uhř́něves, Czech Republic, ${ }^{2}$
} ${ }^{2}$ Kielanowski Institute of Animal Physiology and Nutrition, Polish Academy of Sciences, Jabłonna, Poland

Received July 27, 2002

Accepted November 18, 2002

\begin{abstract}
Šimůnek J., A. Wójcik-Gładysz, M. Wańkowska, P. Krejčí, J. Polkowska: Effects of Short and Long-term Dietary Protein Restriction on the Rumen Fermentation Activity in Growing Lambs. Acta Vet. Brno 2002, 71: 457-462.

The aim of the present study was to compare the rumen fermentation pattern of growing lambs fed restricted protein diet lasting for a short or a long time. Merino lambs $(n=10)$ were fed for 24 weeks beginning at 12 weeks of age two isocaloric diets containing either a restricted $(\mathrm{R}), 8 \%(\mathrm{n}=$ $6)$ or elevated $(E), 18 \%(n=4)$ level of protein. Ammonia, numbers of protozoa and volatile fatty acids (VFA) were estimated in the rumen fluid collected $18 \mathrm{~h}$ after feeding at 0,12 (short-term) and 24 (long-term) weeks of experiment.

The concentration of VFA was determined by gas chromatography, ammonia was determined colorimetrically with Nessler reagent. The fixed and stained protozoa were counted in a FuchsRosenthal counting chamber. It was found that the level of ammonia in the rumen was significantly $(p<0.05)$ decreased by both, short- and long-term feeding of $\mathrm{R}$ diet. The number of protozoa increased with the age of lambs $(p<0.05)$ in both groups and neither the short nor long feeding of $\mathrm{R}$ diet had a significant effect on this parameter. The long- but not short-term $\mathrm{R}$ diet affected the total level of VFA, which were significantly lower $(p<0.05)$ in R compared to E group. This decrease was caused mainly by lower concentration of acetate and butyrate. The results show that the restriction of protein in the diet of growing lambs had no significant effect on the rumen protozoa numbers. However, only the long-term feeding with R diet resulted in impaired VFA production. In conclusion, inadequate level of protein in the diet of growing lambs disturbs the rumen fermentation but this phenomenon depends on duration of feeding.
\end{abstract}

Protein restriction, rumen activity, lambs, protozoa, VFA

Organisms in pregastric parts of the animal digestive tract can ferment a broad spectrum of various dietary components. Polysaccharide substrates that cannot be otherwise available for the host are degraded mainly to volatile fatty acids. These end-products of polysaccharide degradation are either absorbed into the blood and utilized as energy and carbon sources in animal tissues or can be utilized by ruminal microorganisms as a source of energy. Dietary proteins ingested by ruminants are subjected to varying rates and extent of digestion in the rumen. Ruminal microorganisms can efficiently degrade proteins of the feed to non-protein nitrogen substances. These substances are used for synthesis of bacterial and protozoan biomass and thus they are converted into high quality proteins. Under most dietary conditions, ruminants absorb substantial quantities of their dietary nitrogen as ammonia nitrogen, and as much as $65 \%$ of dietary nitrogen intake can be absorbed as ammonia nitrogen (Rey nolds et al. 1991). Nitrogen of ammonia can be used for microbial protein synthesis when carbohydrates (or VFA) again become available, but if rates of ammonia production are high, the production rate can exceed the utilization rate (Hino and Russell 1987). The type of diet, and in particular the form of carbohydrate, has a marked effect on the composition of rumen microflora (Siddons and Paradine 1981). Therefore diet-induced changes in the rumen microflora are accompanied by changes in the rumen

Address for correspondence:

MVDr. Jiř́ Šimůnek, CSc.

Institute of Animal Physiology and Genetics,

Přátelství 560, 10400 Prague, Uhříněves, Czech Republic
Phone: +420267090509

Fax: +420267710803

iapg.cas.cz

http://www.vfu.cz/acta-vet/actavet.htm 
fermentation pattern. If energy of carbohydrates (or VFA) for microbial growth is not limiting, resulting peptides and amino acids can be used for microbial protein synthesis. If carbohydrates are limiting, a considerable fraction of the protein may further be broken down to ammonia (Hes pell and Bryant 1979). The protein flow to the postruminal parts of digestive tract of adult animals with fully developed ruminal fermentation can be significantly influenced by fermentation activity of the ruminal microorganisms. The presence of ciliate protozoa is associated with considerable turnover of protozoa themselves and of bacteria ingested by them. Therefore substantial part of protein passing into the duodenum is composed of both bacterial and protozoan biomass.

Numerous papers on protein degradability in the rumen and protein outflow into abomasum have been published, and attention has been paid to bacterial proteolysis, deamination and proteosynthesis. The possibilities of application of non-protein nitrogen sources instead of expensive protein diet components in the ration were studied in detail as well. But there is no information available on ruminal fermentation changes of animals fed low protein diet. Therefore, the present study was carried out to examine the changes of fermentation pattern in growing lambs after seriously restricted protein feeding lasting for a short or long time.

\section{Materials and Methods}

Animals and experimental procedure

The present study was performed on female Merino lambs born in the second half of December. After weaning, at the age of 9-10 weeks they were transported from the Bieganowo Farm to the Institute of Animal Physiology and Nutrition (Jablonna, Poland). Ten lambs of similar weight $(\sim 26 \mathrm{~kg})$ were maintained indoors in double pens. Photoperiod, light intensity, temperature and flow of air were similar to natural ambient and changed seasonally. They were fed commercial concentrate mixture for growing lambs ad libitum. Beginning at 12 weeks of age they were divided into two groups, and received two diets equilibrated energetically but containing different protein levels. One group $(n=6)$ received restricted $(R)$ protein concentration, $48 \%$ less than required, the other group $(n=4)$ received a diet containing elevated (E) protein concentration, $9 \%$ more than required (according to Polish Nutrient Requirement), for a period of 25 weeks. Composition of diets, macronutrients and micronutrients and net energy values are shown in Table 1. Rations of both diets were equal at the level of $5 \%$ of body weight daily. Net energy value was estimated as $5 \mathrm{MJ} \mathrm{kg} \mathrm{DM}$ and contents of protein as $8 \%$ and $18 \%$ for R and $\mathrm{E}$ groups respectively. Rations were divided into 2 equal portions given at about 08.00 and $14.00 \mathrm{~h}$. The daily food allowance was $9.8 \%$ of the metabolic body weight BW-kg ${ }^{0.75}$ adjusted every 2 weeks for the actual body weight. The animals were weighed every two weeks and regularly inspected by a veterinarian. Three periods of feeding were chosen for sampling of rumen fluid: " 0 "- the day before beginning of experimental feeding, $12^{\text {th }}$ week, short-term experimental feeding and $24^{\text {th }}$ week, long-term experimental feeding.

Table 1

Composition of diets and macronutrients (\% of dry matter), micronutrients (g/kg) and net energy (MJ/kg DM)

\begin{tabular}{|l|c|c|}
\hline & Restricted & Elevated \\
\hline Feeds & & \\
Meadow hay & 6.52 & 33.1 \\
Oat straw & 33.33 & 6.47 \\
Soybean meal & 0.00 & 25.23 \\
Dried sugar beet pulp & 60.00 & 35.05 \\
\hline Macronutrients & 8 & 18 \\
protein & 1.4 & 1.7 \\
fat & 28.7 & 22.1 \\
carbohydrates & 57.5 & 51.5 \\
crude fibre & Vit. E- $1.5 ;$ Fe- $0.5 ;$ Zn- $2.5 ;$ Mg- $6.5 ;$ Co- $0.015 ;$ Mn- 3.0; \\
N-free extractives & J - 0.01; Se- 0.003; Na- 60.0; Ca- 240; P- 120. \\
\hline Micronutrients & 5 & 5.5 \\
\hline
\end{tabular}


All described procedures were approved by the Ethics Committee at the Kielanowski Institute of Animal Physiology and Nutrition in Jabłonna, according to the Polish Guide and Use of Animals.

\section{Sampling}

The rumen fluid was collected from each experimental animal by using a stomach tube at $0,12^{\text {th }}$ (short-term) and $24^{\text {th }}$ (long-term) week of experiment. To eliminate pulses in ruminal fermentation the samples were taken $18 \mathrm{~h}$ after feeding. The samples mentioned for biochemical analyses were preserved by $\mathrm{K}_{2} \mathrm{Cr}_{2} \mathrm{O}_{7}$ addition and stored at $-18^{\circ} \mathrm{C}$ until analysis.

\section{Analyzes}

The concentrations of acetate $\left(\mathrm{C}_{2}\right)$, propionate $\left(\mathrm{C}_{3}\right)$, isobutyrate $\left(\mathrm{i}-\mathrm{C}_{4}\right)$, butyrate $\left(\mathrm{C}_{4}\right)$, isovalerate $\left(\mathrm{i}-\mathrm{C}_{5}\right)$ and valerate $\left(\mathrm{C}_{5}\right)$ were determined in centrifuged samples by gas chromatography using a column of the Chromosorb WAW with $15 \%$ SP 1200 and $1 \% \mathrm{H}_{3} \mathrm{PO}_{4}$ (Supelco), and a flame ionization detector. The separation was carried out at $140^{\circ} \mathrm{C}$. Ammonia concentration was determined in samples clarified by centrifugation ( $8000 \mathrm{~g}$ for $20 \mathrm{~min}$ ) colorimetrically with Nessler reagent (after prior separation from interfering compounds by microdiffusion in Conway units.

\section{Counting of protozoa}

Protozoa were fixed by mixing the samples with the same volume of a fixing solution consisting of $6 \%$ formaldehyde, $0.8 \% \mathrm{NaCl}$ and $0.03 \%$ methyl green. The fixed and stained protozoa were counted in a FuchsRosenthal counting chamber. Only protozoa showing no sign of disintegration were counted (Hino et al. 1973). The numbers of protozoa were expressed as numbers of protozoan bodies per $\mathrm{ml}$ of rumen fluid.

\section{Statistical evaluation}

The significance of differences between the elevated and restricted groups was evaluated by the t-test, all data were subjected to analysis of variance using the General Linear Model Procedure (SAS, 1985).

\section{Results and Discussion}

Results of the ammonia concentration, counts of protozoa and the total VFA concentration are given in Fig. 1. The nitrogen level in the rumen was significantly $(p<0.05)$ decreased by both, short-term and long-term feeding in restricted group in comparison to elevated ones. The rumen microorganisms can efficiently degrade proteins of the feed to non-protein nitrogen substances. These substances are used for bacterial and protozoan biomass synthesis and thus they are converted into high quality

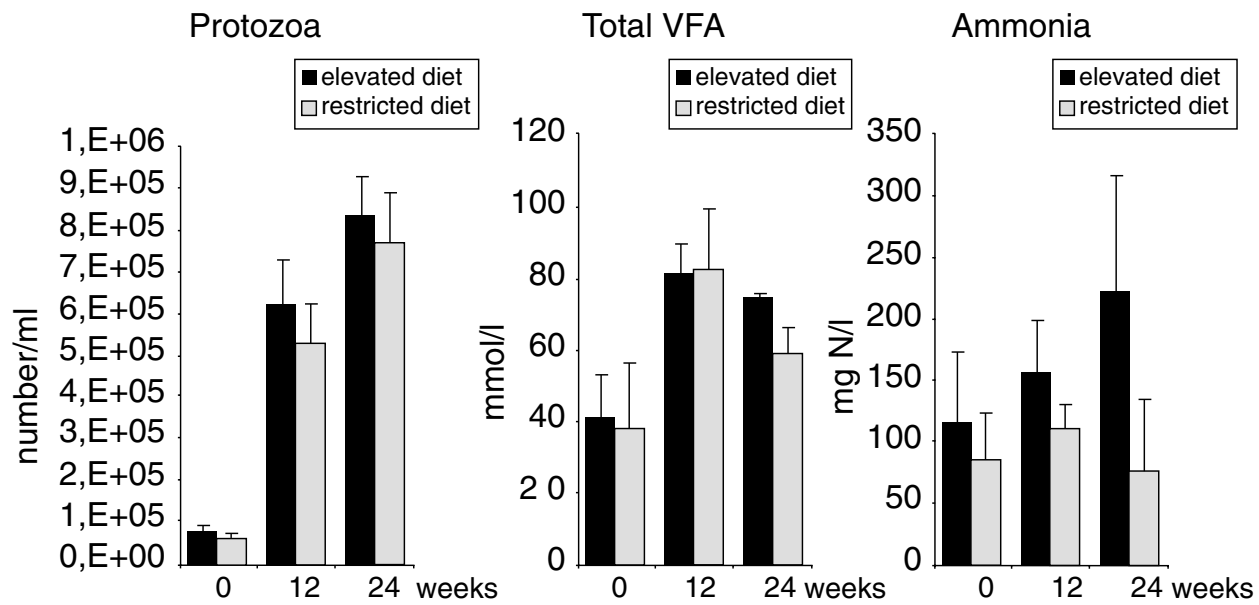

Fig. 1. Protozoan counts, total volatile fatty acids and ammonia concentrations in the rumen fluid of lambs fed diets containing elevated $(18 \%)$ and restricted $(8 \%)$ protein levels at the beginning, $12^{\text {th }}$ and $24^{\text {th }}$ week of the experiment. Vertical bars represent the S. D. values. 
proteins. Under most dietary conditions, ruminants absorb substantial quantities of their dietary nitrogen as ammonia nitrogen, and as much as $65 \%$ of dietary nitrogen intake can be absorbed as ammonia nitrogen (Reynolds et al. 1991). In our experiments higher levels of ammonia found in animals fed elevated protein diet were caused by higher accessibility of protein to bacterial degradation. Nitrogen of ammonia can be used for microbial protein synthesis when carbohydrates become again available, but if rates of ammonia production are high, the production rate can exceed the utilization rate (Hin o and Russell 1987). The protein supply to the intestine of the ruminant is the net result of the microbial protein synthesis and the microbial action on the feed proteins (Lindberg 1984).

The number of protozoa in the rumen fluid increased with the age of lambs. The protozoan population in newborn lambs is very small and the counts of protozoa increase steadily for several months (Fonty et al. 1984). In our experiments the numbers of protozoa were after 12 weeks approximately 6 times higher and reach 60000 protozoan bodies per $\mathrm{ml}$ in both

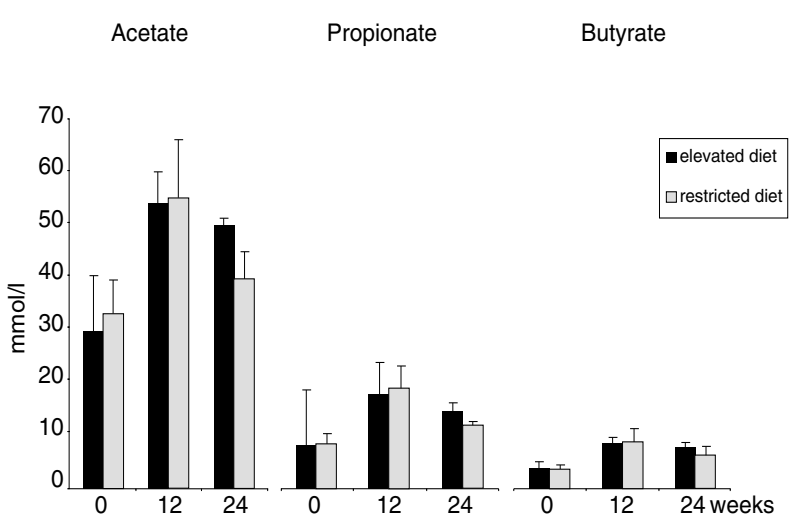

Fig. 2. Acetate, propionate and butyrate concentrations in the rumen fluid of lambs fed diets containing elevated (18\%) and restricted $(8 \%)$ protein levels at the beginning, $12^{\text {th }}$ and $24^{\text {th }}$ week of the experiment. Vertical bars represent the S. D. values.

i-Butyrate i-Valerate Valerate

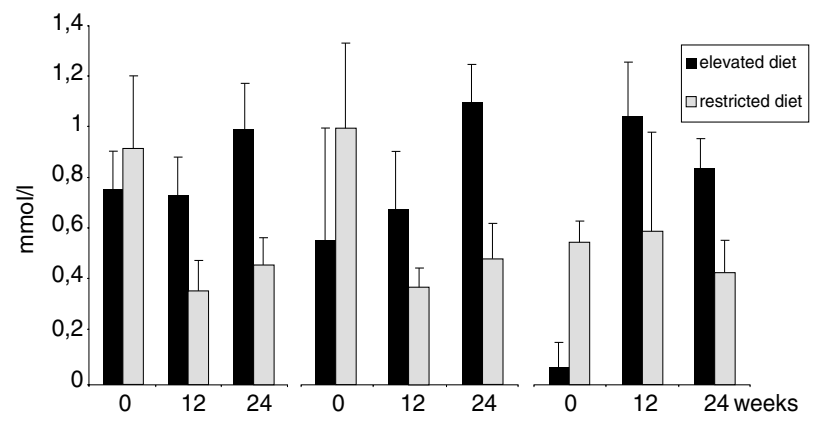

Fig. 3. Isobutyrate, isovalerate and valerate concentrations in the rumen fluid of lambs fed with diets containing elevated (18\%) and restricted $(8 \%)$ protein levels at the beginning, $12^{\text {th }}$ and $24^{\text {th }}$ week of the experiment. Vertical bars represent the S. D. values. groups $(p<0.05)$. At the end of the experiment the counts were 850000 and 790000 protozoa in the group fed elevated and restricted diets, respectively. Similar data were described in adult sheep by Jouany et al. (1992) and Punia et al. (1987, 1992). They found the mean numbers of protozoa 9.3 $\mathrm{x} 10^{5} / \mathrm{ml}$ in the rumen fluid of adult sheep. In all samples of the rumen fluid collected from the animals fed the high protein diet we found not statistically significant differences. Similarly, Ankrah et al. (1990) described no effect of dietary protein level on the protozoan counts. Bird and Leng (1978) described a negative effect of ciliate protozoa on growth and performance of animals fed low protein diets. This finding was not confirmed in our experiments. Results obtained during the past decade indicate clearly that protozoa are actively involved in the degradation of dietary and microbial proteins in the rumen (Jouany 1996).

Long-term but not short-term restricted feeding affected the total level of the volatile fatty acids. The total VFA 
concentration at the beginning of experiment reached $40 \mathrm{mmol} / \mathrm{l}$, approx. (Fig. 1). The concentration of total VFA in $12^{\text {th }}$ week was doubled and reached the level $80 \mathrm{mmol} / \mathrm{l}$, while the VFA concentration found in $24^{\text {th }}$ week was 74.3 and $59.3 \mathrm{mmol} / \mathrm{l}$ in elevated and restricted diet, resp. (Fig. 1). The difference was found to be statistically significant $(p<0.01)$.

The concentrations of acetate, propionate and butyrate are given in Fig. 2. From the data it follows that the lower total VFA in $24^{\text {th }}$ week was caused mainly by significant $(p<0.05)$ depression of acetate and propionate levels (Fig. 2) in animals fed the low protein diet. The concentration of butyrate was not influenced. On the other hand, isobutyrate, isovalerate and valerate levels (Fig. 3) in animals fed protein restricted diet were significantly lower $(p<0.05)$ except of non-influenced valerate in $12^{\text {th }}$ week of the experiment. Similar VFA proportions were found by Siddons and Paradine (1981) in rumen fluid of sheep with lucerne diet.

In conclusion, the level of protein in the diet of growing lambs had no significant influence on the total number of protozoa in the rumen fluid, regardless of period of feeding. The longterm, but not short-term feeding of growing lambs with restricted protein diet impaired the production of VFA.

\section{Vliv krátkodobého a dlouhodobého omezení příjmu proteinu v dietě na bachorovou fermentační aktivitu rostoucích jehňat}

Cílem práce bylo porovnání bachorové fermentace rostoucích jehňat krmených krátkodobě a dlouhodobě dietou s omezeným obsahem proteinu. Jehňata plemene Merino $(n=10)$ byla od stáři 12 týdnů krmena po dobu 24 týdnů dvěma isokalorickými dietami s nízkým (R), $8 \%$ a zvýšeným obsahem proteinu (E), 18\%. V bachorové tekutině odebrané $18 \mathrm{~h}$ po krmení na počátku pokusu a ve 12. a 24. týdnu pokusu byla stanovena koncentrace amoniaku, těkavých mastných kyselin (TMK) a počty prvoků. Koncentrace TMK byla stanovena metodou plynové chromatografie, amoniak byl stanoven kolorimetricky Nesslerovým činidlem. Prvoci byli spočítáni po fixaci a obarvení ve Fuchs-Rosenthalově komůrce. Bylo zjištěno, že hladina amoniaku byla statisticky významně $(p<0,05)$ nižší při krátkodobém i dlouhodobém krmení nízkoproteinovou dietou. Počty prvoků se zvyšovaly v obou skupinách se stářím zviŕrat $(p<0,05)$, doba podávání diety na tento parametr neměla významný vliv. Dlouhodobé podávání nízkoproteinové diety významně snížilo $(p<0,05)$ koncentraci celkových TMK. Tento pokles byl způsoben zejména nižší koncentrací acetátu a butyrátu. U krátkodobého podávání nízkoproteinové diety jsme tento posun nezaznamenali. Výsledky ukazují, že restrikce dietního proteinu u rostoucích jehňat nemá významný vliv na počty bachorových prvoků. Dlouhodobé podávání nízkoproteinové diety ovlivnilo produkci TMK a amoniaku. Lze shrnout, že nedostatečný obsah proteinu v krmné dávce rostoucích jehňat naruší bachorovou fermentaci, ale tento fenomen závisí na době proteinové restrikce.

\section{Acknowledgements}

This work was supported by The Grant Agency of Czech Republic, Grant No. 523/99/603, the Commitee for Scientific Research, Grant no 5 PO6D 006 15, and Czech Academy of Sciences / Polish Academy of Sciences (Poland) Exchange Programme No. 6. f

\section{References}

ANKRAH, P, LOERCH, SC, KAMPMAN, KA, DEHORITY, BA, 1990: Effects of defaunation on in situ dry matter and nitrogen disappearance in steers and growth of lambs. J Anim Sci 68: 3330-3336

BIRD, SH, LENG, RA, 1978: The effects of defaunation of the rumen on the growth of cattle on low-protein highenergy diets. Br J Nutr 40: 163-167

HESPELL, RB, BRYANT, MP, 1979: Efficiency of rumen microbial growth: Influence of some theoretical and experimental factors on YATP. J Anim Sci 49: 1640-1659

HINO, T, KAMETAKA, M, KANDATSU, M, 1973: The cultivation of rumen oligotrich protozoa. II. Growth of entodinia in vitro. J Gen Appl Microbiol 19: 325 
HINO, T, RUSSELL, JB, 1987: Relative contributions of ruminal bacteria and protozoa to the degradation of protein in vitro. J Anim Sci 64: 261-270

FONTY, G, JOUANY, JP, SENAUD, J, GOUET, PH, GRAIN, J, 1984: The evolution of microflora, microfauna and digestion in the rumen of lambs from birth to 4 months. Can J Anim Sci 64 (Suppl.): 165-166

JOUANY, JP, 1996: Effect of rumen protozoa on nitrogen utilization by ruminants. J Nutr 126 (Suppl.): S1335S1346

JOUANY, JP, IVAN, M, PAPON, Y, LASSALAS, B, 1992: Effects of Isotricha, Eupdiplodonium, Epidinium + Entodinium and a mixed population of rumen protozoa on the in vitro degradation of fish meal, soybean meal and casein. Can J Anim Sci 72: 871-880

LINDBERG, JE, 1984: Nitrogen metabolism in sheep. Swedish J Agric Res 14: 37-43

PUNIA, BS, LEIBHOLZ, J, FAICHNEY, GJ, 1987: The role of rumen protozoa in the utilization of paspalum (Paspalum dilatatum) hay by cattle. British J Nutr 57: 395-406

PUNIA, BS, LEIBHOLZ, J, FAICHNEY, GJ, 1992: Rate of production of protozoa in the rumen and the flow protozoal nitrogen to the duodenum in sheep and cattle given a pelleted diet of lucerne hay and barley. J Agric Sci, Cambridge 118: 229-236

REYNOLDS, CK, TYRELL, HF, REYNOLDS, PJ, 1991: Effects of diet forage-to-concentrate ratio and intake on energy metabolism by visceral tissues. J Nutr 121: 1004-1015

SAS User's Guide, 1985. Statistics, 5 ed., SAS Institute, Inc., Cary, NC.

SIDDONS, RC, PARADINE, J, 1981: Effect of diet on protein degrading activity in the sheep rumen. J Sci Food Agric 32: 973-981 